Cornell University Law School Scholarship@Cornell Law: A Digital Repository

Spring 2016

\title{
Executive Opportunism, Presidential Signing Statements, and the Separation of Powers
}

Daniel B. Rodriguez

Northwestern University, Pritzker School of Law

Edward H. Stiglitz

Cornell Law School, js2758@cornell.edu

Barry R. Weingast

Stanford University

Follow this and additional works at: http://scholarship.law.cornell.edu/facpub

Part of the Constitutional Law Commons, and the Law and Politics Commons

\section{Recommended Citation}

Daniel B. Rodriguez, Edward H. Stiglitz, and Barry R. Weingast, "Executive Opportunism, Presidential Signing Statements, and the Separation of Powers," 8 Journal of Legal Analysis 95-119 (2016)

This Article is brought to you for free and open access by the Faculty Scholarship at Scholarship@Cornell Law: A Digital Repository. It has been accepted for inclusion in Cornell Law Faculty Publications by an authorized administrator of Scholarship@Cornell Law: A Digital Repository. For more information, please contact jmp8@cornell.edu. 


\title{
EXECUTIVE OPPORTUNISM, PRESIDENTIAL SIGNING STATEMENTS, AND THE SEPARATION OF POWERS
}

\author{
Daniel B. Rodriguez*, Edward H. Stiglitz ${ }^{* *}$, and Barry R. Weingast***
}

\begin{abstract}
Executive discretion over policy outcomes is an inevitable feature of our political system. However, in recent years, the President has sought to expand his discretion using a variety of controversial and legally questionable tactics. Through a series of simple separation of powers models, we study one such tactic, employed by both Democratic and Republican presidents: the use of signing statements, which purport to have status in the interpretation of statutory meaning. Our models also show that signing statements upset the constitutional vision of lawmaking and, in a wide range of cases, exacerbate legislative gridlock. We argue that courts should not legally credit signing statements; we conclude by discussing executive opportunism broadly.
\end{abstract}

\section{INTRODUCTION}

According to many observers, our constitutional system is run through with executive opportunism. ${ }^{1}$ The tools of opportunism defy a census, but include at least executive agreements with foreign entities, executive orders unsupported by or contrary to statutes, informal guidance documents that escape the Administrative Procedure Act (APA) and its safeguards, regulations that exceed or at least strain statutory authority, systematic non-enforcement of statutory provisions, and presidential signing statements. Moreover, the

* School of Law, Northwestern University, Chicago, IL, USA.

* Law School, Cornell University, Ithaca, NY, USA. Email: jedstiglitz@gmail.com.

*** Department of Political Science, Stanford University, Stanford, CA, USA. We thank participants at workshops at the Hoover Institution and UC Berkeley School of Law, as well as Josh Chafetz, Chris Walker, and an anonymous referee for very helpful comments on earlier drafts. We thank the Hoover Institution and our respective universities for research support.

1 See, e.g., the submissions for the Hoover Institution conference entitled "The Role of Executive Power and Discretion under the Rule of Law." For another recent entry in this area, see Freeman \& Spence (2014), which examines agencies' adaptations of old statutes to confront newly arising problems.

(C) The Author 2016. Published by Oxford University Press on behalf of The John M. Olin Center for Law, Economics and Business at Harvard Law School.

This is an Open Access article distributed under the terms of the Creative Commons Attribution Non-Commercial License (http://creativecommons.org/licenses/by-nc/4.0/), which permits non-commercial re-use, distribution, and reproduction in any medium, provided the original work is properly cited. For commercial re-use, please contact journals.permissions@oup.com doi:10.1093/jla/lav013 
policy areas affected by such tools ever-more appear to represent some of the most important choices faced by our democracy: for example, how to confront the problem of climate change, or how to reform our immigration policies. Here and elsewhere, the Executive behaves opportunistically, upsetting settled expectations about the admittedly hazy constitutional boundaries of his legitimate authority.

Our objective in this article is to offer a positive analysis of one important form of executive opportunism, ${ }^{2}$ one that accounts for the behavior, not only of the Executive himself, but also of other institutional actors. To focus the analysis, we examine executive opportunism through the window of presidential signing statements, with the hope of thereby generating insights about the more general phenomenon. Signing statements represent a particularly attractive tool of opportunism to study because of their historical prominence-with presidents of both parties using them widely-and because they fit into the otherwise familiar setting of statutory interpretation, emphasizing the important role that courts might play in helping to define the contours of permissible executive authority.

Presidential signing statements enable the president to express his views about legislation, to explain why he is signing the law and to state his view on the constitutionality of the law. More controversially, these statements can, and not infrequently do, declare what he will or will not enforce or implement in this new legislation or will describe how, in the president's view, the courts or agencies should interpret the law. This latter tactic understandably riles many commentators, insofar as it reflects post-legislative executive opportunism and arguably threatens the Constitution's separation of powers. To put the objection in sharp terms, through these types of signing statements, those in which the president declares in a statement that he will construe the relevant statute to accord with his interpretation, the president is selectively invalidating parts of laws passed by both chambers of Congress. ${ }^{3}$

The normative objections to presidential signing statements are substantial and complex. This tactic indeed raises fundamental questions, including: what is the proper relationship between the President and Congress in the legislative process? What are the appropriate limits on Presidential control over regulatory administration? To what extent does the Constitution's separation of powers limit executive influence over the implementation of laws? We believe that the normative positions can be evaluated only when we have a clear understanding

2 We describe this as executive opportunism, and not merely executive action, to more precisely capture the point that the executive is often acting against settled expectations regarding his likely behavior.

3 We provide a basic taxonomy of signing statements below. 
of how signing statements impact the policy-making process. To that end, our analysis in this article centers on the question of what effect, if any, signing statements have on public policy and on the strategic behavior of institutional actors. Do policy outcomes differ-and if so, in what way? How does the Congress respond to the president's use of signing statements? Without first knowing how signing statements might affect the legislative and administrative process, we cannot evaluate their normative implications.

To address the question of how signing statements affect the legislative process, we adopt varying assumptions regarding the legal authority of signing statements. We begin this analysis with a standard model of the legislative process, and then add signing statements to study their influence. ${ }^{4}$ Although the existing literature has recognized that signing statements potentially have a direct effect on statutes (see, e.g., Kinkopf 2007; Bradley \& Posner 2006; Rodriguez 1992; Cross 1988), arguably effectively invalidating legislative provisions passed by Congress, the literature has failed to anticipate the subtler and more important indirect effects we focus on.

Our main theoretical results show the following: because signing statements, if given legal effect by courts, ${ }^{5}$ change the meaning of an act, rational legislators will take them into account in the legislative process. Building on this basic premise, our models show that, in a wide range of cases, Congress prefers the status quo-that is, no legislation-to legislation followed by a presidential signing statement. Moreover, as we show, signing statements result in a startling constitutional "role reversal," with the legislature issuing vetoes, and the president in substantial measure determining the content of the laws. Our most basic

4 Application of positive political theory to understanding the legislative process, particularly interacting with courts, include: Cohen \& Spitzer (1994), Eskridge and Ferejohn (1991), Ferejohn and Weingast (1992), and Marks (2012). See McCubbins \& Rodriguez (2006) for a recent survey of the field.

5 We emphasize that signing statements have an uncertain position in statutory interpretation. Some courts appear to treat signing statements as irrelevant, influencing neither the statute's meaning nor its constitutional status. A 9th Circuit decision, for example, recently suggested that presidential signing statements have little value in determining legislative intent, Yakima Valley Memorial Hosp. v. Wash. State Dep't of Health, 654 F.3d 919 (9th Cir. 2011). To varying degrees, other courts treat presidential signing statements as legitimate interpretive aids regarding legislative intent. The DC Circuit, for instance, referred to President H.W. Bush's signing statement when assessing whether the Torture Victim Protection Act, otherwise silent on the issue, created a cause of action for claims of torture committed by private individuals. Saleh v. Titan Corp., 580 F.3d 1, 16 (D.C. Cir. 2009); see also, Berry v. Dept. of Justice, 733 F.2d 1343 (9th Cir. 1984). Similarly, a court relied on President H.W. Bush's signing statement to determine that the Civil Rights Amendments of 1991 applied only prospectively. McCullough v. Consolidated Rail Corp., 785 F. Supp. 1309 (N.D. Ill. 1992). Thus far, courts have adopted a variety of positions on the appropriate uses of presidential signing statements as a tool of statutory interpretation. We examine different assumptions about the legal status of signing statements, and in this way address the question of whether courts should give legal meaning to the statements. 
results indicate that presidential signing statements have a potentially pernicious effect on the legislative process specified in Article I, Section 7 of the Constitution.

We also consider cases where legislation delegates authority to a bureaucratic agency, examining several assumptions about bureaucratic motivations. We show that delegating to a bureaucracy reduces some of the dysfunctions associated with traditional lawmaking. However, signing statements often re-aggravate the lawmaking process, diminishing the moderating benefits of bureaucratic delegation, and again increasing legislative gridlock. The absence of legislation and the prevalence of the status quo policies means that a wide range of national problems go unresolved as Congress prefers no legislation to the outcome of legislation biased by signing statements.

Based on our positive analysis, we argue that the use of such statements by courts in interpreting statutes results in an inversion of the constitutionally prescribed lawmaking process, and further discourages cooperation between the president and Congress, a functional consideration of great importance under the prevailing conditions of inter-branch polarization (e.g., McCarty, Pool \& Rosenthal 2006; Volden \& Wiseman 2011). For many of the same reasons, and contrary to a common view, we also conclude that signing statements should not necessarily receive the traditional deference that courts give to agencies' post-enactment interpretation of statutes.

In this way, we suggest several general points about executive opportunism. First, if opportunism is prevalent, coordinate branches of government are likely, over time, to anticipate it and to adapt their behavior to mitigate its implications. Second, these responses by other branches may, in fact, reduce the welfare of the executive himself. For example, in our account, Congress is more likely to allow the status quo policy to linger out of distrust for what the executive will do if granted new authority. But we might conjure other legislative responses; to imagine one possibility, Congress might engage in dangerous budgetary brinkmanship in an attempt to starve executive action or to publicly chasten the executive. Such legislative responses may make the executive - to say nothing of the public-worse off than he is in world wherein executive opportunism is not present. The difficulty, of course, is that the president cannot help himself from behaving opportunistically. This suggests, third, an important role for the courts, helping to delineate the permissible boundaries for legislative authority; boundaries that make all actors better off, including the president. We focus on the context of signing statements and statutory interpretation, but again, the same insight applies to other contexts, such as the scope of the executive's authority to systematically not enforce statutory provisions and, more generally, executive branch control over the process and content of regulatory administration. 
This article proceeds as follows. We first present several fundamental empirical patterns regarding presidents' use of signing statements in the post-war period. We then analyze several models of signing statements, first considering the case of legislation where no bureaucracy is needed, then considering the cases of bureaucratic implementation. Our normative conclusions follow.

\section{EMPIRICS: REGULARITIES AND DESCRIPTIVES}

Several preliminary empirical questions call for attention. Perhaps most pressing: how commonly does the president employ signing statements? By their own terms, what do signing statements purport to accomplish? In what areas of policy does the president use signing statements?

To address these questions, we develop a novel dataset of signing statements that spans the post-war period. Other scholars have tallied the number of signing statements issued by presidents (e.g., Ostrander \& Sievert 2013; Bradley \& Posner 2006; Cooper 2005), but they do not always provide an appropriate denominator (but see Kelley \& Marshall 2008; Berry 2009). The denominator is a crucial consideration: for example, by our counts, President Reagan issued just over twenty relevant signing statements in both 1986 and 1989. However, Congress passed almost twice as many laws in 1986 as it did in 1989 , meaning that the likelihood of the president attaching a signing statement to a law in 1989 was about double the figure for 1986 (roughly, 10 percent in 1989; 5 percent in 1986). Along the same lines, to our knowledge, no previous effort has fully accounted for the policy areas addressed in signing statements. ${ }^{6}$ How many statements attach to bills relating to national security, for example, a traditional area of executive prerogative? Healthcare? Civil rights? And so on.

Scholars generally divide signing statements into several categories based on what they purport to accomplish and the legal authority they rely on (Dellinger 1993; Kelley 2003; Bradley \& Posner 2006). We follow a more or less common set of distinctions between what might be termed constitutional statements, interpretive statements, and celebratory statements. In the first category of statements, the president declares that, under his view of the constitution, some statutory provision is unconstitutional, or would be unconstitutional in some circumstances, or will be interpreted in a fashion to avoid some threatening constitutional infirmity (Dellinger 1993). In the second category, the president uses the statement to interpret some statutory provision, arguably inserting his views into

6 For example, Ostrander \& Sievert (2012) argue that the president uses signing statements to protect traditional areas of executive authority, such as foreign affairs, and they collect data informative to this view, but they do not categorize statements by policy area more generally. 
the meaning of the statute (Dellinger 1993). Notice that the president may interpret a provision precisely to avoid what amounts, in his view, to a constitutional defect in the statute. Finally, and least controversially, the president may simply announce, explain, or celebrate what has been achieved in a statute.

Our focus is on interpretive signing statements, though, as suggested above, this class of statements sometimes runs into the class of constitutional statements. Although presidents employed statements to interpret statutes from time to time through much of American history, presidents did not begin to systematically use them for this purpose until Reagan (Popkin 1991; see also Kelley 2003, 2007), who recognized that signing statements might be an effective tool to influence the downstream behavior of agencies and courts. To this end, Reagan's Attorney General famously arranged to have presidential signing statements included with legislative history from Congress in West's influential U.S. Code Congressional and Administrative News, "so that all can be available to the court for future construction of what that statute really means" (Meese 1986, quoted in Dellinger 1993; see also de Figueiredo 2012). Since Reagan, legal scholars have argued over whether statements represent proper authorities in matters of statutory interpretation (see, e.g., Garber \& Wimmer 1987; Popkin 1991; Dellinger 1993; Calabresi 2006; Bradley \& Posner 2006; Kim 2008).

Much remains unresolved, but it is in any event clear that President Reagan used signing statements to interpret statutes aggressively. As Popkin (1991) observes, for instance, President Reagan declared in a signing statement attached to the Safe Drinking Water Act Amendments of 1986 that provisions calling for mandatory enforcement of violations "infring[ed] on the powers of the Executive," a highly debatable constitutional position that also contradicted the plain text of the statute, which provided that the EPA "shall issue an order" and "shall commence a civil action" under the relevant circumstances."

Consistent with this historical narrative, data supports the proposition that the Reagan administration represented a turning point in executive practices with respect to signing statements. In Figure 1, we plot the two panels: on the left, the number of public laws for which the president includes a signing statement interpreting provisions over time; on the right, the proportion of public laws that have such a signing statement. ${ }^{8}$ Each dot in this figure

7 Pub. L. $99-339$.

8 We collect the text of the signing statements from UCSB's American Presidency Project. We categorize a signing statement as interpretive if it (i) mentions a "provision" or "section" of the law, and (ii) purports to "interpret" or "construe" it, or discusses how the president will "implement" or "treat" the provision, or mentions the constitution in connection with the provision or section. For roughly five percent of signing statements, the text does not reveal the public law number, and we exclude these from our analysis. 
Figure 1. Signing statements over time.
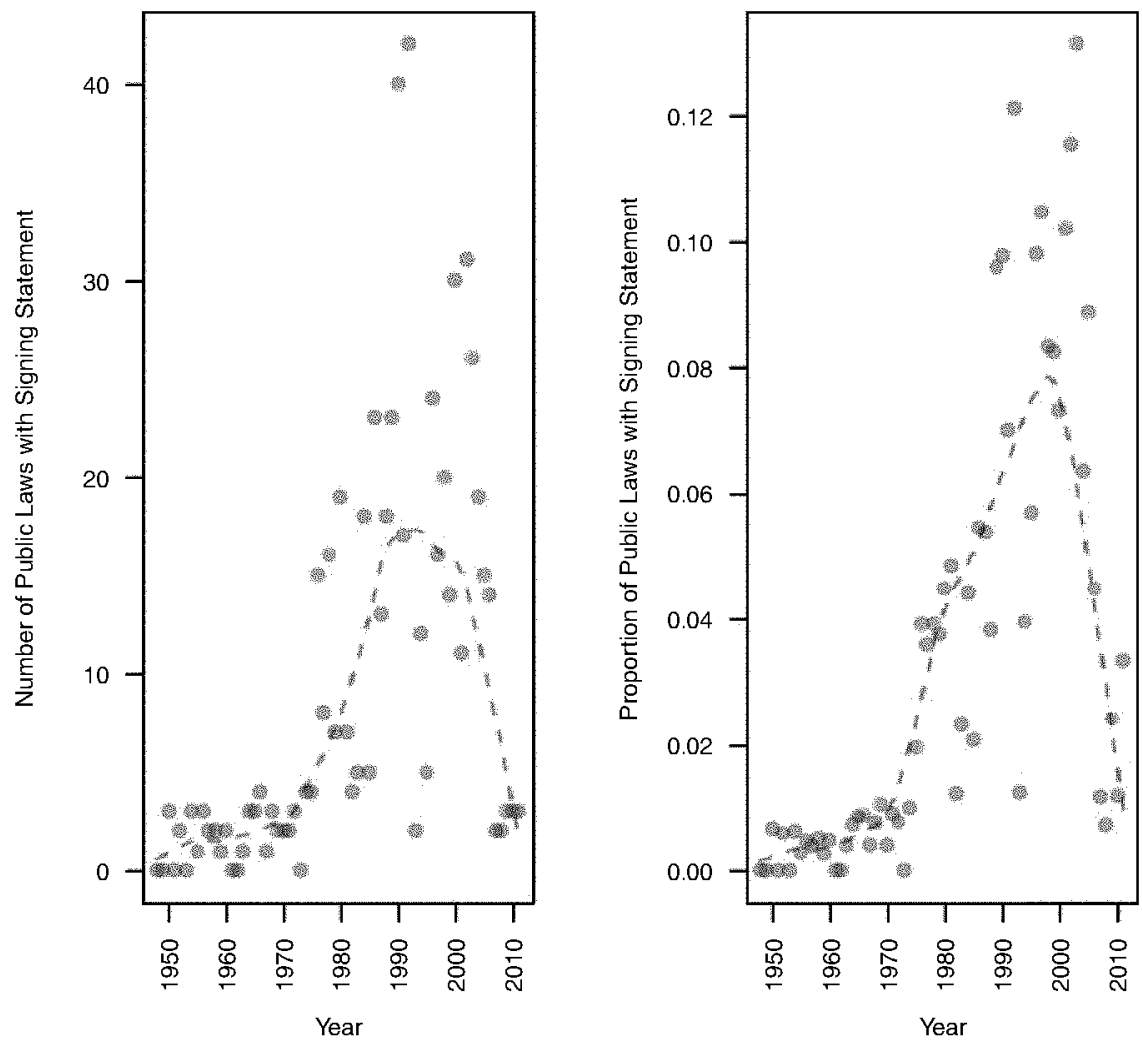

represents the number (left panel) or proportion (right panel) of public laws with interpretive signing statements attached to them in a given year; the dashed line shows the locally weighted average for these quantities (Cleveland 1979). As is evident from this figure, presidents issued relatively few substantive signing statements until the early 1980s. At that point, presidents dramatically increased their use of signing statements, a pattern that persists in the main through both Democratic and Republican administrations. The number of signing statements then declined markedly post 2006 , when a vigorous public debate erupted regarding the propriety of the statements. We now live in an era with a nearly pre-Reagan incidence of signing statements, but the debate over the propriety of statements continues as many issues remain unresolved and presidents in the future may re-invigorate the tool, as such tools enhance presidential influence over the policy-making process.

Before turning squarely the analysis of signing statements over the modern time period, we pause to clarify the context in which presidents issue signing statements. One potentially misleading observation in the commentary on such 
statements derives from the fact that, to a large extent, the recent public debate over signing statements arose in the context of a larger debate about executive power and the war on terrorism. The tacit assumption here is that the vast majority of signing statements deal with matters of foreign policy and the executive's role as commander in chief. This is not accurate. Not all, or even most, of presidential signing statements concern foreign policy. Indeed, in what we believe to be the most complete analysis of the topics covered by signing statements, we find that only about one-quarter of signing statements attach to public laws concerning foreign policy. ${ }^{9}$ It is true that the president is far more likely to issue a signing statement for a bill contending with foreign policy than domestic policy: he writes a signing statement for roughly 4.5 percent of foreign policy bills, compared to roughly 2.5 percent of domestic policy bills. However, the president issues signing statements for some areas of domestic policy, such as environmental policy, with a much greater likelihood than for foreign policy. We observe considerable heterogeneity within domestic policy.

To demonstrate this point, in the left panel of Figure 2, we present the number of interpretive signing statements issued by presidents between 1950 and 2011, broken down by the topic of the bill in question; the right panel shows the proportion of bills in each policy area with a signing statement. Most significantly, this simple figure reveals that presidents issue interpretive signing statements on a wide range of policy issues; in fact, conditional on being presented a bill, he is most likely to issue statements on contentious domestic issues: civil rights and the environment. Thus, though foreign policy represents an important area of policy for signing statements, the vast majority of statements in fact attach to public laws concerning domestic policies, and the public laws most likely to receive a signing statement fall in the domestic arena.

A second important contextual point is that a president is far more likely to write a signing statement for an important law than a trivial one. The Congressional Quarterly Almanac contains a list of "key votes" in each Congress, reflecting CQ's assessment of the votes in a given Congress that represent "a matter of great controversy," "a test of presidential or political power," or a "decision of potentially great impact on the nation and lives of Americans." ${ }^{10}$ We examine the lists of key votes and determine whether each

9 For this exercise, we extract the public law number from the signing statement and use the public law number to generate a mapping to the Policy Agendas Project Public Laws Dataset. This dataset contains the "major" topic of each public law passed between 1950 and 2011. In our coding, "foreign policy" includes immigration, foreign trade, foreign aid, and defense. Of the nearly 600 interpretive signing statements in our dataset, just over 150 address bills focusing on foreign policy.

10 See http:/library.cqpress.com/congress/html/help/Help_keyVote.htm. 
Figure 2. Signing statements by policy area.

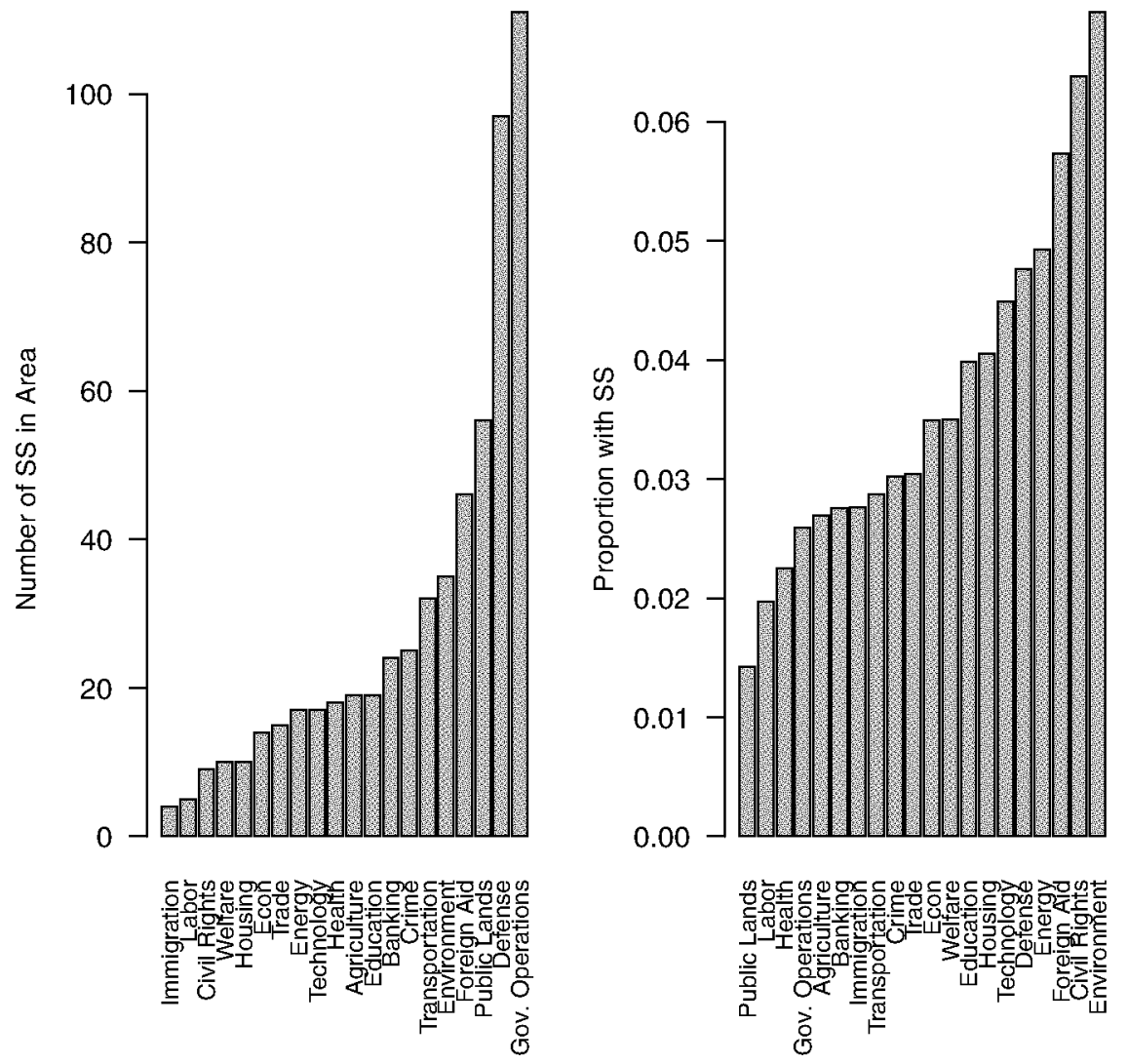

public law in our database is associated with such a vote. ${ }^{11}$ This exercise indicates that signing statements condition heavily on the importance of the public law. Overall, our data indicate that presidents write statements for about 3 percent of all public laws. By comparison, 21 percent of key public laws have signing statements. ${ }^{12}$ Thus, it is the most important public laws-not the trivial ones - that tend to attract the president's attention in signing statements.

11 In particular, we determine whether the bill number identified by CQ matches the House or Senate bill number listed in Policy Agenda's dataset within a year. Note that the number of "key votes" will generally exceed the number of associated "key public laws" for a number of reasons: (i) some key votes result in the defeat of a measure; (ii) some key votes refer to resolutions, (iii) in some cases, the bill number will change between the key vote and passage.

12 We find an increase of similar magnitude for key public laws when we examine this issue in a regression framework; the result survives year and issue fixed effects. 


\section{AN ANALYSIS OF SIGNING STATEMENTS}

\subsection{Preliminaries}

The objective of our analysis is to describe in the simplest possible form the strategic interaction among several branches of government and to chart the implications of possible judicial practices with respect to signing statements. We describe analytically the consequences of what signing statements might be, if taken seriously by courts. This, as we suggest in our introduction, ought to inform anyone's normative views about the desirability of giving legal effect to signing statements. ${ }^{13}$ Our first two models include only the president and the Congress; our second two models additionally include a bureaucracy.

When we analyze the potential effects of signing statements, we assume that they have the force of law; that is, that these statements are not just advisory statements akin to a memo from the White House to agencies. Notice that this position conflicts with Bradley and Posner (2007), who write that "the President... can uncontroversially announce [his] views about the constitutionality of a statute in other contexts," such as an internal memo, and that the statement does little more than enhance the transparency of the President's constitutional views. This suggests a generous perspective on Presidential behavior: he is motivated by a desire to increase the transparency of the political process. We adopt the more conventional assumption that the President is primarily motivated by policy objectives (see, e.g., Krehbiel 2010; Howell 2013). In our view, he issues statements precisely because they might have colorable legal force and confer policy benefits that cannot be achieved through internal memos or campaign speeches.

\subsection{Model 1A: Original Legislation}

We study the Article I, Section 7 legislative process in the context of a president and Congress that have diverging views over the most appropriate public policy, $p$. In the simple family of models we consider, the policy choice is binary: the policy-making organs of government can set $p=1$ or $p=0$. This choice might reflect, for example, a decision to increase or decrease pollution

13 We are aware of a few other recent efforts to model signing statements, but they have a different objective than our study; they seek to understand the conditions under which a president might issue a signing statement (Cutrone 2008; Thrower 2014; Moraguez 2014, notably examining signing statements and legislative bargaining). Given the unsettled nature of judicial doctrine in this area, we orient toward the legal questions: to understand what policy, constitutional, and normative implications might follow from signing statements if they are regarded as binding by courts; ultimately, we wish to speak to whether courts should give them credit beyond what they would give presidential statements made in a memo or a campaign speech. 
control requirements, or to spend more or less on the military. ${ }^{14}$ Against this policy choice, actors weigh the benefits provided to them by the status quo policy, $q$, which is defined over the interval $[-1,1]$.

We represent the diverging views of the constitutional actors in the following way: $u_{E}(p)=p$ and $u_{C}(p)=(1-p)$, where we use " $\mathrm{E}$ " to subscript payoffs for the president, and " $C$ " to subscript payoffs for the Congress. Thus, the executive prefers to set $p=1$ and the Congress prefers to set $p=0$. By comparison, in the absence of a policy, both the president and the Congress receive a payoff of $u(q)=q$. Notice that because $q$ is defined over negative values, Congress and the president often face an incentive to cooperate on public policy.

The structure of policy-making follows the contours of Article I, Section 7. First, we begin with a randomly chosen status quo; in technical terms, nature selects a status quo, $q$, from the distribution F defined over $[-1,1]$. Second, the Congress chooses between legislation in which he sets $p$, or the status quo, $q$. If it is the latter, then the interaction ends, and all receive their payoffs. Third, if the Congress legislates, the president decides whether to veto the legislation, after which the game ends. ${ }^{15}$ If he vetoes the legislation, the status quo remains intact; otherwise the congressional policy goes into effect.

This interaction produces a simple equilibrium outcome, which we find by working backwards from the final move. ${ }^{16}$ At this stage, the president clearly vetoes any legislation that makes him worse off. In technical terms, E vetoes the legislation - assuming there is legislation-if and only if the benefits or "utility" of the status quo outweigh the benefits of the policy, $u_{E}(p)<u(q)$. This means that when $q<0$ the president will not veto the policy, regardless of whether $p=1$, as he prefers, or $p=0$, as Congress prefers; when $q<0$ the president does better with either policy than with the status quo. Because the president prefers $p=1$ to all other policies, this veto strategy also means that the president never vetoes the policy when $p=1$.

Working back a stage in calculating the equilibrium, we note that Congress anticipates the veto behavior of the president. Seeing that the president does not veto legislation when $q<0$ the Congress sets $p=0$ when the status quo is in that part of the interval. By contrast, when $q>0$ either Congress or the president prefers the status quo to the policy payoffs of legislation. That is, under the status quo, both constitutional actors receive a positive payoff, whereas under legislation one or the other actor receives a payoff of zero: if Congress sets $p=0$,

14 Note that this is a common simplifying assumption in the modeling literature. See, for example, Canes-Wrone, Herron \& Shotts (2001), Maskin \& Tirole (2004), and Fox \& Jordan (2011).

15 Without great loss, we ignore the constitutional wrinkle raised by veto overrides.

16 The solution concept is subgame perfection. 
the president receives a payoff of zero and therefore vetoes the legislation; were Congress to set $p=1$, Congress receives a payoff of zero, so it will not do so. Thus, the equilibrium policy outcome in this interaction is straightforward: if $q<0$ the policy outcome is $p=0$, which improves the welfare of both the president and the Congress relative to the status quo; if $q>0$ the president and Congress cannot agree on a policy, and the status quo remains.

Although simple, this model reflects our constitutional structure and demonstrates results common to separation of powers models in the positive political theory literature (e.g., Brady \& Volden 1998, 2005; Krehbiel 2010; Clark 2009). First, when the status quo policy is highly unpleasant to both constitutional actors, these actors have an incentive to cooperate even in the face of profound disagreements over policy. Second, because Congress is the first mover and the president possesses only veto and not amendment powers, policy outcomes tend to favor congressional preferences. Notice that when there is legislation, it reflects Congress's preferred policy (Romer \& Rosenthal 1978). Third, over a wide range status quos, Congress and the president cannot agree on how to improve policy, and the status quo remains intact

\subsection{Model 1B: Legislation with Signing Statements}

Under the standard view, the president uses signing statements to "reinterpret the language of the bill so as to coincide with his own views" (Garber \& Wimmer 1987, p. 366). We model signing statements in a manner that reflects this assumption. In this model, we allow the president to "reinterpret" the statute. Specifically, in the model we allow $\mathrm{E}$ to reset $p$ after Congress has chosen to produce legislation. That is, this case replicates model $1 \mathrm{~A}$, which describes the originalist notion of legislation, except we permit the president to change the value of $p$ in the legislation, in addition to vetoing the legislation.

This revised interaction featuring signing statements also produces a simple equilibrium policy outcome. Again proceeding by backwards induction, if there is legislation the president faces no incentive to veto; he is always better off with $p=1$ than with any value of $q$. As a result, the president sets $p=1$ through a signing statement any time that Congress produces legislation. Congress anticipates this behavior by the president and knows that, if it passes legislation, its payoff will be $u_{C}=(1-p)=0$. This means that the Congress is better off with the status quo any time that $q>0$, and is better off with a statute, as reinterpreted by the president, any time that $q<0$.

Thus, as with originalist legislation, policy disagreement between the constitutional actors produces zones of cooperation as well as a zone of "gridlock." In our simple family of models, these two zones in fact coincide in the two models: regardless of signing statements, the president and the Congress cannot agree 
on policy when $q>0$ and no legislation is produced. However, signing statements produce a form of constitutional "role reversal": with signing statements, Congress is relegated to veto-issuing role (albeit ex ante rather than ex post); the Executive determines the ultimate character of the policy. Treating signing statements with the force of law allows the president to assert a dramatic power over Congress.

\subsection{Model 2A: Original Legislation with Bureaucracy}

We now consider the effect of signing statements in the case where Congress and the president have decided to delegate the policy choice to an administrative agency. For nearly a century, administrative agencies have implemented the vast majority of legislative acts (Eskridge \& Ferejohn 1992). Indeed, one view is that the president is principally speaking to administrative agencies when issuing signing statements. The question, therefore, is how bureaucratic implementation influences the effect of signing statements.

Scholars employ a range of assumptions about the preferences of the bureaucracy and its role in producing public policy. Some scholars argue that ex ante procedures combine with expost incentives to make bureaucrats faithful to the enacting president and Congress. Favoring presidential control, one might point to appointments, (generally) removal, (generally) OIRA review, ${ }^{17}$ as well as more informal methods of influence, such as public statements in support of or in opposition to regulatory positions (see generally Eskridge \& Ferejohn 1992; Kagan 2001). ${ }^{18}$ Favoring congressional control, one might point to Congress's primacy in budgeting its control over the structure of agencies and the procedures they employ (McNollgast 1987), more generally its ability to write specific and constraining statutes, its ability to hold oversight hearings (Aberbach 2001). Finally, other scholars emphasize the power of both constitutional actors, with the resulting power creating a bargaining game between them. For example, the president may have the power of appointment, but the Senate must confirm the president's most important appointees (Synder \& Weingast 2000; McCarty 2004). Indeed, most empirical studies of the bureaucracy suggest that agencies respond to both political principals and that neither completely controls (e.g., Bertelli \& Grose 2011). We acknowledge these heterogeneous approaches; for the purposes of this article, we remain agnostic about bureaucratic preferences, representing them as a parameter in our model.

To model a bureaucracy under plural control, we consider a simple stochastic bureaucracy, in which the administrative agency effectively flips a (possibly

17 For a counterweight to this point, consider Nou (2013).

18 Consider, for instance, President Obama's role in changing the FCC's position on net neutrality. 
weighted) coin over the policy alternatives. We do not mean to suggest that this is literally how agencies select policies, and such a method of policy making would certainly run afoul of the APA, if not the Constitution. However, from the perspective of Congress and President, it may be difficult to determine the bureaucracy's choice ex ante. In fact, the widely varying assumptions that scholars use when modeling the bureaucracy reflect the many, oftencontradictory forces that influence bureaucratic behavior. Given this background, at the time Congress passes a bill or the president signs it, the political principals will often not have perfect information about how agencies will implement the statute. In this sense, from the ex ante perspective of Congress or the president, bureaucratic behavior may appear to contain an element of "randomness."

We model this feature of $\mathrm{C}$ and E's perspective on bureaucratic implementation by building in a stochastic component to the agency's decision. Let the bureaucracy set $p=1$ with probability $\beta \in[0,1]$ and $p=0$ with probability $1-\beta$. The larger is $\beta$ the more likely the bureaucracy sides with the president, and the smaller is $\beta$ the more likely it sides with the Congress. Thus, $\beta$ can be viewed as a parameter reflecting the relative control that the president and Congress exert over the agency, with larger values indicating greater presidential control.

We append the bureaucracy to the Article I, Section 7 structure described above; the new sequence of the interaction is as follows. First, nature selects a status quo, q. Second, the Congress decides whether to legislate or not. If not, the status quo remains intact, the interaction ends, and all players receive their payoffs. Third, if the Congress legislates, the president decides whether to veto the legislation. If he vetoes, the status quo remains intact, the interaction ends, and all players receive payoffs. If he does not veto the legislation, fourth, the bureaucracy sets $p=1$ with probability $\beta$ and $p=0$ with probability $1-\beta$. Notice that the bureaucracy is not a strategic actor in our model; to the extent it has preferences, they should be understood as induced by tools of presidential and congressional control, reflected in the value of $\beta$.

Working backward, we note that the president vetoes the legislation when the expected payoff from the policy is less than the payoff from the status quo. Put another way, the president will sign the legislation when it makes him better off in expectation; the president is better off signing the legislation, on average, when $\beta$, the probability the agency sets $p=1$, the president's preferred policy, exceeds $q$, his payoff from the status quo. Formally, when $E\left[u_{E}(p)\right]>u_{E}(q) \Rightarrow \beta>q$, the president signs the bill and the agency implements the policy. Sensibly, the greater the influence he has over the bureaucracy, the more willing is the president to sign a bill delegating authority to the bureaucracy. The Congress, likewise, legislates when the expected payoff from 
legislating is greater than the payoff from the status quo: that is, in the context of the payoffs described above, when the probability the bureaucracy sides the congress, is greater than the payoff from the status quo, or in other words, when $E\left[u_{C}(p)\right]>u_{C}(q) \Rightarrow 1-\beta>q$. Also sensibly, the Congress is more willing to legislate when it exerts more control over the bureaucracy.

An important result from this interaction is that, subject to various political conditions relating to $q$ and $\beta$, the bureaucracy inspires cooperation among the constitutional actors. These two variables are the principal parameters of the model that help explain how political conditions affect policy choice by $\mathrm{C}$ and $\mathrm{E}$. We can neatly explain policy choice as a function of these parameters. Figure 3 plots the policy outcome as a function of $q$ and $\beta$. To see the relationship of policy choice to the parameters, observe that when $q<0$, both $\mathrm{C}$ and $\mathrm{E}$ prefer C's ideal policy of 0 to $q$ (the president receives a payoff of zero in this context). Hence, both constitutional actors will support legislation moving policy from $q$ to 0 . As this is true for any value of the status quo, $q$, greater than -1 and less than 0 , we darken the region 1 in the figure in the same way, indicating that the same equilibrium occurs, although the specific values of $q$ and $\beta$ may differ.

The figure has four additional regions, labeled 2-5, that depend on whether $q<\beta$ and whether $1-\beta>q$. As each of the two inequalities may be satisfied or not, they give us a total of 4 cases, with political behavior differing depending on the case. In Region 5, with large values of $q$ and intermediate values of $\beta$, both constitutional actors prefer the status quo to policy change, and $q$ is the policy equilibrium. Regions 3 and 4 represent values of $q$ and $\beta$ where one of the actors desires new legislation, but the other does not: in Region 3, the president vetoes any legislation, and in Region 4 Congress prefers not to pass any legislation. Gridlock occurs in Regions 3 and 4. The most interesting political circumstance is Region 2: this region represents a moderate bureaucracy and relatively unappealing status quos. For values of $q$ and $\beta$ in this region, have legislation, but only in the presence of the bureaucracy. Here, that is, we have both $\beta>q$ and $1-\beta>q$, such that Congress enacts legislation, and the president signs it, despite the fact that $q>0$.

In this way, the bureaucracy induces cooperation between the president and Congress that would otherwise not be possible. Recall from model $1 \mathrm{~A}$ that, absent the bureaucracy, the constitutional actors cannot agree on a new policy for any $q>0$; now, with a bureaucracy, we sometimes have legislation even when $q>0$. Strategically, this is possible because the bureaucracy effectively allows both the Congress and the president to commit, in expectation, to a "moderate" policy rather than a policy that fully reflects the values of one or other of the president or the Congress. Without this commitment device, either 
Figure 3. Equilibrium in presence of bureaucracy.

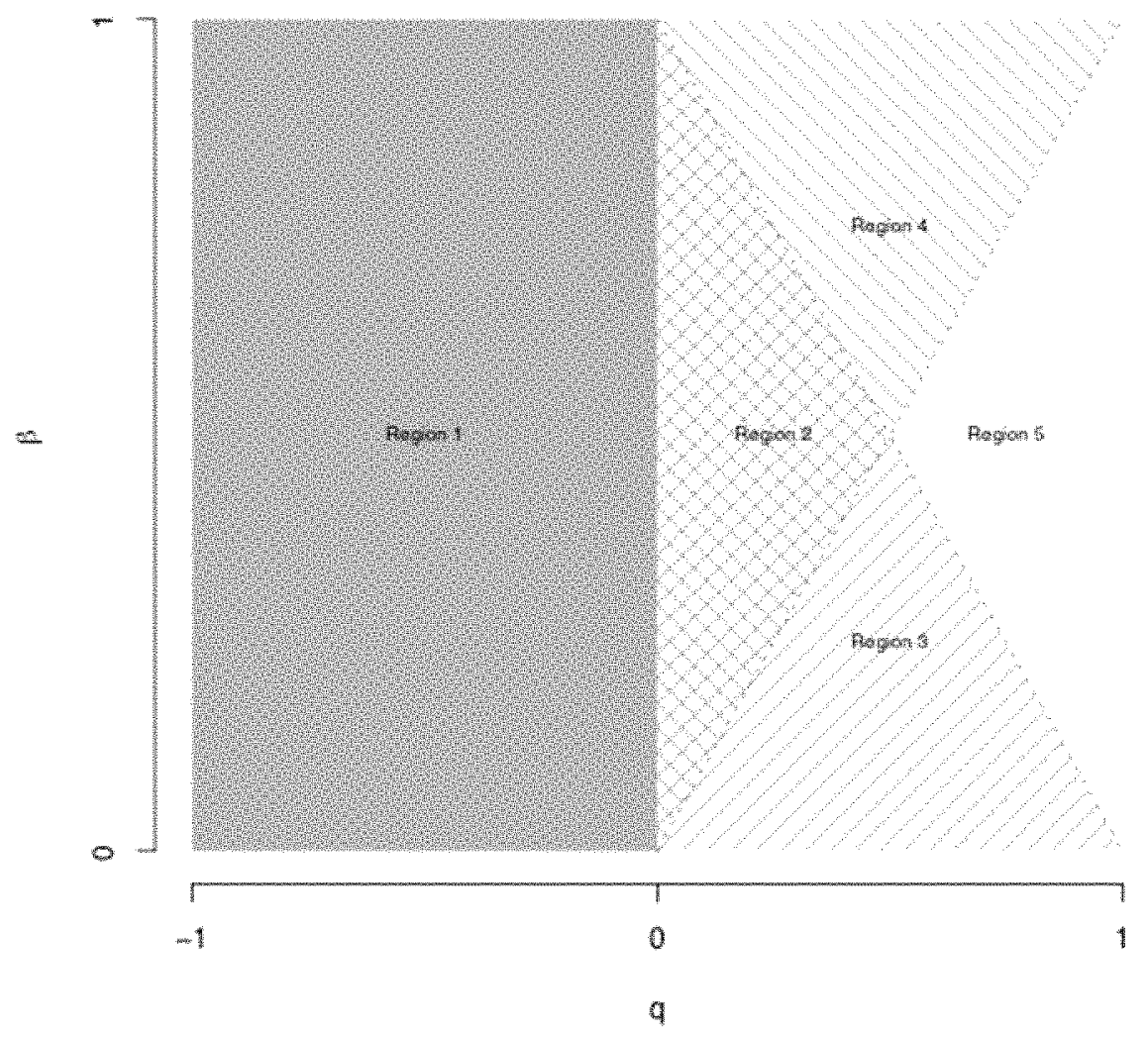

the president or the Congress prevails, and this hardline induces a breakdown in lawmaking. ${ }^{19}$

Importantly, as the bureaucracy becomes more "politicized" (e.g., Lewis 2003), the value of the administrative state as a commitment device diminishes. This can be seen by noting that both the president and Congress cooperate on legislation only when $q<\beta<1-q$, which is difficult to satisfy when $\beta$ is large or small. The inequality is most easily satisfied, in the sense that it encompasses the largest possible interval of status quos, when $\beta=\frac{1}{2}$, so that the bureaucracy is balanced between Congress and the president; that is, it is equally likely that the bureaucracy will favor the president or the Congress.

19 The notion of delegation as a commitment device is widespread in the literature. For example, Rogoff (1985) suggests delegation to an independent central bank to thwart problems of dynamically inconsistent preferences; Melamud \& Mookerjee (1989) have a similar finding in the tax context. However, to our knowledge, scholars have not studied delegation as a means of fostering Congress-Executive cooperation, as we do in this analysis. 


\subsection{Model 2B: Legislation with Bureaucracy and Signing Statements}

In the context of the bureaucracy, we model signing statements by allowing them to influence the probability that the agency selects a policy consistent with the president's views. If the president issues a signing statement, the probability that the agency sets $p=1$ is $\beta+s$, where $s \in[0,1-\beta]$. We take $s$ to be an exogenous parameter reflecting the incremental influence that a signing statement gives the president in the bureaucratic implementation of the statute. The value of $s$ might reflect, for instance, the weight that courts give to signing statements, a topic we discuss below. The sequence of the interaction is identical to that in model $2 \mathrm{~A}$, but now, in addition to vetoing the legislation, the president may approve it with a signing statement.

A preliminary observation is that the president faces no incentive to withhold a signing statement if he signs the bill, as doing so increases the probability the policy aligns with his views, and this advantage comes at no cost to him. With this in mind, and building off the discussion above, it is apparent that we end up with an equilibrium of the following nature: the president signs the bill, with a statement, when $E\left[u_{E}(p)\right]=\beta+s>q$. When signing statements grant the president more control over the bureaucracy, or when his signing statements carry a great deal of weight with the courts, then these statements make it more likely that the president will sign the bill. The Congress, likewise, legislates when the expected payoff from legislating is greater than the payoff from the status quo: $E\left[u_{C}(p)\right]=1-\beta-s>q$. The Congress is more willing to legislate when it exerts more control over the bureaucracy, and when signing statements carry less weight.

Signing statements have a potentially dramatic influence over the behavior of the constitutional actors. Generally, they make the president more willing to sign legislation, if passed by Congress. But they also make Congress less likely to pass legislation. This can either increase or decrease the ability of the constitutional actors to cooperate in making public policy. To see this, note that signing statements shift (in expectation) the bureaucracy toward the president's preferred position. This means that if $\beta>\frac{1}{2}$, such that the bureaucracy is already pre-disposed to support the president, the signing statements result in an increasingly "politicized" bureaucracy that reduces the interval of status quo policies over which the Congress and the president might reach agreement. In the context of Figure 3, signing statements mean we move up the downward sloping edge joining Regions 2 and 4, reflecting a shrinking interval in the status quos greater than zero over which both actors prefer legislating to not. By comparison, if $\beta<\frac{1}{2}$ signing statements potentially result in a less politicized bureaucracy, as they shift induced bureaucratic preferences away from Congress and toward an intermediate position. In particular, so long as $\beta<\frac{1}{2}$, if signing 
statements do not exert too much influence, such that $s<1-2 \beta$, they in fact enlarge the interval of status quos over which the constitutional actors cooperate; by contrast, if $s>1-2 \beta$, the signing statement results in a bureaucracy that favors the president (more than it had previously favored the congress), and the signing statement reduces the interval over which inter-branch cooperation is possible.

Several important implications emerge from this variation of the model. First, as above, the presence of the bureaucracy improves the ability of the president and Congress to reach agreements. The bureaucracy, in effect, represents a device that allows the elected officials to tie their hands and to discourage opportunism; it allows the branches to overcome commitment problems that often prevent them from addressing pressing public policy concerns. Second, signing statements often, but not always, serve to diminish the usefulness of the bureaucracy in this respect. Any time that the bureaucracy already favors the president $\left(\beta>\frac{1}{2}\right)$, signing statements undermine the ability of the branches to cooperate. However, signing statements of modest effect can enhance the ability of the branches to cooperate if the bureaucracy is predisposed to favor Congress $\left(\beta<\frac{1}{2}\right)$. We return to this point below. Third, notice that when signing statements diminish the ability of the branches to cooperate, the president himself wants to commit to use them, but he cannot help himself from doing so; he uses them despite himself. We also return to this point below.

\section{THE LEGAL STATUS OF SIGNING STATEMENTS}

The sequence of positive models reveals a range of interesting results about the effects of signing statements on legislation. Some of these effects are straightforward, but some are subtle and strategic, and these effects have typically gone unnoticed in the literature. Most obviously, signing statements illustrate our point about executive opportunism. These statements dramatically affect the legislative process, as designed by the Constitution in Article I, Section 7. By allowing the president to adjust legislation after the fact, signing statements allow the president to marginalize the role of Congress with respect to writing the legislation. ${ }^{20}$ Congress retains a veto over legislation-albeit an ex ante

20 We readily acknowledge that president does, and ought to, contribute to the debate over the constitutionality of legislation during the process by which it is being considered in Congress. He has every right to warn Congress that a bill will be vetoed if passed because of his view that the statute would be unconstitutional. And, of course, he could (and should) negotiate with Congress to ensure that the enacted bill meets his conditions. The "after the fact" characteristic of signing statements is the fundamental difference with regard to this technique. It is quite unrealistic to suppose that Congress will "vote" on the views of the president when they are expressed after enactment. 
rather than ex post veto-but little more. In anticipation of the dramatic effects of signing statements, Congress will exercise its veto extensively, preventing legislation that allows the president to alter legislation to his ideal policy. This form of legislative "role reversal" is at odds with the plain text of the constitution. To the extent that constitutional text serves as a normative benchmark, we should disapprove of signing statements.

Several scholars argue that signing statements are unconstitutional in that they grant the president a role not anticipated by the Constitution (e.g., Garber and Wimmer 1987); others make the more moderate claims that statements should be disregarded by courts because they are in no way probative of statutory meaning and legislative intent (e.g., Popkin 1991). We argue that signing statements have a much larger, negative effect on the legislative process in that they allow the president to neutralize the role of Congress in writing the details of legislation. Thus, beyond signing statements representing a departure from constitutional lawmaking, they mark a reversal of lawmaking as envisioned in the Constitution.

In studying the role of the bureaucracy, our positive study reveals a novel and nuanced view into legislative dynamics set off by signing statements. As indicated above, the bureaucracy often allows the Congress and president to reach agreements that would not otherwise be possible. Signing statements sometimes help facilitate such cooperation-by making the bureaucracy more moderateand sometimes impede such cooperation-by making the bureaucracy overly sympathetic to the president. To the extent we wish to facilitate more cooperation between the branches in lawmaking, these points serve as another normative benchmark. For example, we might want to encourage such cooperation because, in the absence of democratic lawmaking, social problems tend to get addressed by other, less democratically accountable branches of government (e.g., Eskridge 2012).

In policy areas where the president generally exerts more control over the bureaucracy than Congress, our normative conclusion is that courts should not credit signing statements as informative pieces of legislative history. ${ }^{21}$ Doing so tends only to produce more disagreement between Congress and the president, inducing legislative gridlock and effectively allowing less accountable appendages of the government resolve our social problems. What is more, the president himself tends to want courts to ignore signing statements - in fact, he does best when signing statements do not matter. But if the courts take signing statements seriously, the president cannot help himself from using them. The courts can,

21 We do not undertake in this paper to offer any data about how often the courts credit presidential signing statements. However, as noted above, courts occasionally do look to such statements in their interpretations. 
therefore, serve as a commitment technology for the president by tying his hands and allowing him to credibly agree not to use signing statements, or more accurately to do so ceremonially only. ${ }^{22}$

At the same time, if courts do credit signing statements as informative pieces of legislative history, they should do so with respect to the agencies that most align with the Congress, as doing so results in a less politicized bureaucracy that encourages cooperation between the branches. Most centrally, this means that courts might want to consider crediting signing statements for statutes delegating authority to independent agencies, but to withhold from doing so with respect to executive agencies. Because independent agencies come under weaker presidential control-they largely fall outside the purview of the Office of Information and Regulatory Affairs, and the president obviously has diminished removal powers over their officers-Congress has greater relative control over their behavior, and signing statements may allow the president to generate a more moderate bureaucratic implementation of the statute.

Several scholars have argued that signing statements deserve deference in their own right (Calabresi \& Lev 2007; Bradley \& Posner 2006). Here our views largely follow the discussion above. In particular, the validity of our position depends on both doctrinal and functional considerations.

Doctrinally, the conceit underlying the Chevron doctrine is that an ambiguity in the statute represents an implicit delegation by Congress to agencies: we infer from the existence an ambiguity in a statute a congressional intent to permit the agency to decide the matter. How reasonable is it to view ambiguities as implicit delegations to the president, rather than to an agency? We view this inference as shaky at best. Congress may delegate to agencies for a number of reasons that do not apply to the president himself: the expertise of the agency, the fact that Congress exerts an important measure of downstream control over the agency, and the fact that the agency must follow congressional specified procedures when interpreting and implementing the statute (McNollgast 1987). By comparison, the president is a generalist, not an expert, Congress has relatively little influence over his downstream behavior, and plainly there is no APA analog for signing statements.

Moreover, as above, there is a functional concern with deferring to signing statements in these contexts. Signing statements often work at cross-purposes

22 In saying "ceremonially," we do not deny that there may be significant values to issuing signing statements wholly apart for their putative impact on the legislation's interpretation. Through these statements, the president can alert the executive branch to her enforcement priorities, can notify regulated individuals as to how the law will be enforced, where there is discretion to do so, and can more transparently announce his intentions to refuse to enforce. We are grateful to Nate Persily for his observations along these lines at the Hoover Institution conference. 
with delegations generally. Delegations to the bureaucracy help to facilitate interbranch cooperation, permitting the lawmaking organs to address pressing public policy problems. However, as argued above, where signing statements result in an overly politicized bureaucracy that favors the president, ${ }^{23}$ they undermine the cooperative space created by delegation to the bureaucracy. Of course, as we also show, in those instances in which the agency is predisposed to favor Congresslikely a minority of cases, given the structure of the bureaucracy - signing statements may facilitate cooperation by resulting in a more politically neutral bureaucratic implementation. So, we end with somewhat ambivalent conclusion that, as to whether the Chevron doctrine supports or defeats the argument for signing statements in the administrative agency context that "it depends."

\section{CONCLUSIONS}

We have studied signing statements as a window into a broader class of activities in which the executive behaves opportunistically. The heart of this article is a positive model of the effect of signing statements on the legislative process. The model begins with a variant on the standard workhorse model in the literature, allowing us to study the effects of presidential signing statements. Throughout, we have assumed that the courts treat signing statements as an important and legal part of the legislative process. The purpose is not to model what we believe occurs now-we have already observed that courts have yet to treat these statements in any consistent manner; further, no major, precedentsetting case exists that provides a definitive statement of their legal status.

Instead, the purpose of the positive models is to predict under varying conditions how signing statements might affect aspects of the policy-making process. To evaluate the normative characteristics of signing statements, we must first know what they might do. The literature has reached no consensus over the effects of signing statements; it also contains a great many fanciful and fallacious assertions. Relying on positive modeling methods resolves these problems.

More ambitiously, we suggest that the positive political analysis exemplified in this article illuminates the ways in which scholars approach the central normative questions raised. Scholars in the literature tend to approach the question in a static form: what do current doctrines imply about a certain legal question, such as, are signing statements constitutional? The answer to this question cannot be viewed statically, as the analysis of constitutional controversies does entail a consideration of, although not an embrace of the idea that, the constitution as a living document whose meaning evolves over time in response

23 In the language of the model, $s>1-2 \beta$. 
to new circumstances (Balkin 2011). A conspicuous attention to constitutional change and evolution is essential for, at the very least, the positive political reason that, without the ability to adapt to changing circumstances, constitutions are far more likely to fail (on adaptability, see Hayek 1960; North 2006; Mittal 2011; Mittal \& Weingast 2010).

So, with this perspective, we describe the functions of signing statements under the assumptions that Congress and the president engage in strategic behavior to maximize their influence and impact. Moreover, we take a dynamic view of this pattern of behavior, looking not only at Congress-President competition and policy-making tactics, but also at the ways in which the Constitution's structure of lawmaking in Article I, Section 7 properly regulates this competition.

This study of signing statements suggests several lessons that apply broadly to instances in which the executive behaves opportunistically-upsetting settled views about the boundaries of his permissible authority under the Constitution. The first lesson is that coordinate branches of government are unlikely to ignore executive opportunism on signing statements. Instead, Congress is likely to adapt its own behavior to new field of play established by the president: it is likely to attempt to punish the executive for his opportunism, and it is likely to attempt to design legislative schemes that mitigate the effects of the executive's boundary-altering behavior. Our model, for instance, indicates that opportunism may increase legislative gridlock. But we have also seen the Congress engage in numerous other such activities in recent times: withholding funding of the Department of Homeland Security in an attempt to induce the president to withdraw his immigration enforcement guidance, likewise delaying the confirmation of nominations to important executive-branch appointments in retaliation for executive opportunism. ${ }^{24}$

A second lesson is that, in the face of such actions, it is not at all clear that the president himself-to say nothing of the public-is better off in a world in which he behaves opportunistically. For example, our model indicates that signing statements might, if given legal effect by the courts, result in policy inertia that make the president worse off than if he were not permitted to issue such statements. The problem for the president, of course, is that the president cannot commit in advance that, once Congress moves, he will refrain from behaving opportunistically.

Various means exist that potentially constrain the executive-in his own interest - from behaving opportunistically. For example, repeated interactions between the president and the Congress may allow Congress to develop

24 See, e.g., http://www.nytimes.com/2015/04/18/us/politics/republicans-in-quandary-over-vote-onloretta-lynch.html. 
punishment strategies that effectively diminish opportunistic behavior. The development of such strategies, however, requires, most obviously, repetition. It is not clear how effective such strategies will be for second term presidents; indeed, it is probably not a mistake that many of President Obama's most aggressive uses of executive power have come during his second term. And the president is most likely to defect on bills most central to his agenda. This defection, in turn, hinders repeated interaction as a means of policing executive opportunism.

A third lesson is that the courts may play a critical role in helping to delineate the permissible boundaries for legislative authority; boundaries that make all actors better off, including the president. We focus on the context of signing statements and statutory interpretation, but again, the same insight applies to other contexts, such as the scope of the executive's authority to systematically not enforce statutory provisions.

\section{REFERENCES}

Aberbach, Joel D. 2001. Keeping a Watchful Eye: The Politics of Congressional Oversight. Washington, DC: Brookings Institution Press.

Balkin, Jack. 2011. Living Originalism. Cambridge, MA: Harvard University Press.

Berry, Michael J. 2009. Controversially Executing the Law: George W. Bush and the Constitutional Signing Statement. 36 Congress of the Presidency, 244-271.

Bertelli, Anthony M. \& Christian R. Grose. 2011. The Lengthened Shadow of Another Institution? Ideal Point Estimates for the Executive Branch and Congress. 55 Am. J. Polit. Sci. 767-781.

Bradley, Curtis A. \& Eric A. Posner. 2006. Presidential Signing Statements and Executive Power. 23 Const. Comment. 307-423.

Brady, David W. \& Craig Volden. 1998. Revolving Gridlock: Politics and Policy from Carter to Clinton. Westview Pr.

- 2005. Revolving Gridlock: Politics and Policy from Jimmy Carter to George W. Bush. Westview Press.

Calabresi, Steven G. 2006. "The Legal Significance of Presidential Signing Statements", Typescript of testimony, Northwestern University.

Canes-Wrone, Brandice, Michael C. Herron \& Kenneth W. Shotts. 2001. Leadership and Pandering: A Theory of Executive Policymaking. Am. J. Polit. Sci. 532-550.

Clark, Tom S. 2009. The Separation of Powers, Court Curbing, and Judicial Legitimacy. 53 Am. J. Polit. Sci. 971-989. 
Cleveland, W. S. 1979. Robust Locally Weighted Regression and Smoothing Scatterplots. 74 J. Am. Stat. Assoc. 829-836.

Cooper, Phillip J. 2005. George W. Bush, Edgar Allan Poe, and the Use and Abuse of Presidential Signing Statements. 35 Pres. Stud. Q. 515-532.

Cross, Frank B. 1988. The Constitutional Legitimacy and Significance of Presidential "Signing Statements". 40 Admin. L. Rev. 209-238.

Cutrone, Michael. 2008. "Essays on Presidential Signing Statements", Unpublished doctoral Thesis, Princeton University, Princeton.

de Figueiredo, John M. 2012. "Presidential Signing Statements and the U.S. Federal Courts", Typescript, Duke University.

Dellinger, Walter. 1993. The Legal Significance of Presidential Signing Statements. Washington, DC: Department of Justice.

EskridgeJr, William N. \& John Ferejohn. 1991. Article I, Section 7 Game, The. 80 Geo. Lj. 523.

Eskridge, William N. 2012. Vetogates and American Public Law. 84 J. L. Econ. Org. 1441-1494.

Evans, Kevin. 2011. Challenging Law: Presidential Signing Statements and the Maintenance of Executive Power. 38 Congress \& the Presidency, 217-234. Taylor \& Francis Group.

Garber, Marc N. \& Kurt A. Wimmer. 1987. Presidential Signing Statements as Interpretations of Legislative Intent: An Executive Aggrandizement of Power. 24 Harv. J. Legis. 363.

Garvey, Todd. 2012. Presidential Signing Statements: Constitutional and Institutional Implications. Congressional Research Service.

Hayek, Friedrich A. 1960. The Constitution of Liberty. Chicago: University of Chicago Press.

Howell, William G. 2013. Thinking about the Presidency: The Primacy of Power. Princeton, NJ: Princeton University Press.

Kagan, Elena. 2001. Presidential Administration. 114 Harv. L. Rev. 2245-2385. Kelley, Christopher S. 2003. "The Unitary Executive and the Presidential Signing Statement", Dissertation, Miami University.

Kelley, Christopher S. \& Bryan W. Marshall. 2008. The Last Word: Presidential Power and the Role of Signing Statements. 38 Pres. Stud. Q. $248-267$.

- 2010. Going it Alone: The Politics of Signing Statements from Reagan to Bush II. 91 Soc. Sci. Q. 168-187.

Kepplinger, Gary L. 2008. Presidential Signing Statements: Agency Implementation of Selected Provisions of Law. GAO-08-553T.

Kinkopf, Neil. 2007. Signing Statements and Statutory Interpretation in the Bush Administration. 16 William \& Mary Bill of Rights Journal. 307-314. 
Kim, Yule. 2008. Statutory Interpretation: General Principles and Recent Trends. CRS Report for Congress.

Krehbiel, Keith. 2010. Pivotal Politics: A Theory of U.S. Lawmaking. Chicago: University of Chicago Press.

Lewis, David E. 2003. Presidents and the Politics of Agency Design: Political Insulation in the United States Government Bureaucracy, 1946-1997. Stanford, CA: Stanford University Press.

Maskin, Eric \& Jean Tirole. 2004. The Politician and the Judge: Accountability in Government. 94 Am. Econ. Rev. 1034-1054.

McCarty, Nolan. 2004. The Appointments Dilemma. 48 Am. J. Polit. Sci. 413-428.

McCarty, Nolan, Keith T. Poole \& Howard Rosenthal. 2006. Polarized America: The Dance of Ideology and Unequal Riches. Cambridge, MA: MIT Press.

McNollGast. 1987. Administrative Procedures as Instruments of Political Control. J. L. Econ. Org. 243-277.

Moraguez, Ashley. 2014. "Policy Making in the Shadow of Executive Action", Typescript, Emory University.

North, Douglass C. 2010. Understanding the Process of Economic Change. Princeton, NJ: Princeton University Press.

Nou, Jennifer. 2013. Agency Self-Insulation Under Presidential Review.

Ostrander, Ian \& Joel Sievert. 2012. The Logic of Presidential Signing Statements. Polit. Res. Q. 1065912911434357.

Popkin, William. 1991. Judicial Use of Presidential History: A Critique. 66 Ind. L. Rev. 699.

Rappaport, Michael B. 2007. Unconstitutionality of Signing and NotEnforcing, The. 16 Wm. \& Mary Bill Rts. J. 113.

Rodriguez, Daniel B. 1992. Statutory Interpretation and Political Advantage. 12 Intl. Rev. L. Econ. 217-231.

Romer, Thomas \& Howard Rosenthal. 1978. Political Resource Allocation, Controlled Agendas, and the Status Quo. 33 Public Choice. 27-43.

Snyder, Susan K. \& Barry R. Weingast. 2000. The American System of Shared Powers: The President, Congress, and the NLRB. 16 J. L. Econ. Org. 269-305.

Theriault, Sean M. 2008. Party Polarization in Congress. New York: Cambridge University Press.

Thrower, Sharece D. 2014. "Presidential Action and the Supreme Court: The Case of Signing Statements", Typescript, University of Pittsburgh.

Volden, Craig \& Alan E. Wiseman. 2011. Breaking Gridlock: The Determinants of Health Policy Change in Congress. 36 J. Health Polit. Pol. L. 227-264. 